Palimpsest: Journal of Information and Library Science Vol 12, Issue 2, (2021), page 85-98

\title{
Efektivitas Pemakaian Jurnal Online oleh Mahasiswa di Perpustakaan Universitas Riau
}

\section{The Effectiveness of the Use of Online Journals by Students in the Riau University Library}

\author{
Gusla Putri*, Nining Sudiar**, Vita Amelia**** \\ Library Science, Faculty of Humanities, Lancang Kuning University, Indonesia \\ gusput1010@gmail.com
}

\begin{abstract}
Received : $16^{\text {th }}$ October 2021; Revised : $12^{\text {th }}$ November 2021; Accepted : $20^{\text {th }}$ November 2021
\end{abstract}

Available Online : $5^{\text {th }}$ December 2021; Published Regularly $: 5^{\text {th }}$ December 2021

\begin{abstract}
The title of this research is The Effectiveness of the Use of Online Journals by Students in the Riau University Library. This study purposed to understand the effectiveness of online journals in the Riau University Library used by students. The method used in this research is descriptive quantitative. The population of this study is 5.621 student theses in 2019. As many as 373 samples were picked using the random sampling technique. The results showed that the use of the Westlaw online journal was very ineffective, namely 5,89\%, because the effectiveness ratio was below 40 according to the Litbang Depdagri. Other than that, the online journal Emerald is highly ineffective because there is $0 \%$ of Riau University students quoting from the journal in 2019. For the online journal ProQuest, the usage rate is 6,43\%, according to the Litbang Depdagri, also the level of use is very ineffective because the effectiveness ratio is below 40 .
\end{abstract}

Keywords: Use of Online Journals; Libraries.

\begin{abstract}
Abstrak
Judul penelitian ini yaitu Efektivitas Pemakaian Jurnal Online oleh Mahasiswa di Perpustakaan Universitas Riau. Tujuan dari penelitian ini yaitu untuk mengetahui bagaimana efektivitas pemakaian jurnal online oleh mahasiswa di Perpustakaan Universitas Riau. Metode yang digunakan dalam penelitian adalah kuantitatif deskriptif. Dengan jumlah populasi sebanyak 5.621 skripsi dan sampel 373 skripsi mahasiswa pada tahun 2019. Teknik pengambilan sampel menggunakan teknik random sampling. Hasil penelitian menunjukkan bahwa efektivitas pemakaian jurnal online Westlaw sangat tidak efektif yaitu senilai 5,89\%, karena rasio efektivitasnya di bawah 40 sesuai acuan Litbang Depdagri. Sedangkan jurnal online Emerald sangat-sangat tidak efektif karena tidak ada atau senilai 0\% mahasiswa Universitas Riau yang mengutip dari jurnal tersebut pada tahun 2019. Dan untuk jurnal online ProQuest tingkat pemakaiannya senilai $6,43 \%$ sesuai acuan Litbang Depdagri maka tingkat keterpakaiannya sangat tidak efektif karena rasio efektivitasnya di bawah 40.
\end{abstract}

Kata Kunci: Pemakaian Jurnal Online; Perpustakaan

\section{Pendahuluan}


Menurut McMillian (dalam Jamluddin, 2015:40) e-journal adalah serial yang diproduksi, diterbitkan, dan didistribusikan melalui jaringan elektronik seperti bitnet dan internet. Di Perpustakaan, kata jurnal atau jurnal online tidak asing lagi di telinga. Menurut Sholihah (2016:2), jurnal online merupakan sumber digital perpustakaan karena memberikan keakuratan informasi berdasarkan riset ilmiah. Perpustakaan menyediakan dan mengelola jurnal online guna memenuhi kebutuhan pengguna perpustakaan yang sering berubah-ubah. Selain itu, pengguna bisa menjadikannya sebagai bahan referensi dalam menulis karya ilmiah, baik itu oleh mahasiswa, dosen, atau yang lainnya dalam menyelesaikan laporan seperti proposal, skripsi, dan penelitian lainnya. Pengaksesan jurnal online terbagi menjadi dua yaitu gratis dan berbayar. Adapun cakupan dari jurnal online yaitu berisi artikel hasil penelitian dan pandangan para ahli.

Penggunaan jurnal online semakin meningkat dibandingkan jurnal tercetak karena memiliki banyak keunggulan, yaitu jurnal online hemat waktu, biaya, dan tenaga tanpa harus mengunjungi perpustakaan tersebut (Amaliah, 2017:4). Sedangkan kelemahannya ialah tidak memasukkan indeks dan abstrak, sitasi mudah rusak, perubahan URL menjadikan akses ke jurnal online menjadi terganggu bahkan hilang semuanya, mesin pencari mengabaikan file PDF, dan lain-lain (Siswadi dalam Sevilla, 2016:207).

Pada saat ini hampir semua perpustakaan sudah berlangganan jurnal online berupa database jurnal seperti Emerald, JSTOR, ScienceDirect, EBSCOhost, Spingerlink, Britannica, Westlaw, Scopus, Oxford jurnal, dan lain-lain. Akan tetapi tidak semua orang yang dapat mengaksesnya, sebab untuk masuk ke jurnal tersebut harus memasukkan kata kunci atau keyword. Bagi civitas academica, jika berlangganan jurnal online selain mendapatkan referensi lebih dari jurnal yang sudah dibaca, kita juga bisa mengalami kerugian jika tingkat pemakaian jurnal online tidak digunakan atau tidak diakses semaksimal mungkin dengan kata lain biaya yang dikeluarkan perpustakaan tidak sesuai dengan tingkat pemakaian pengguna. Jurnal dikatakan efektif di suatu perpustakaan apabila tercapainya suatu pencapaian atau sasaran terhadap pemakaian jurnal langganan dengan waktu yang telah ditentukan pihak civitas academica.

Sama halnya Perpustakaan di Universitas Riau. Perpustakaan Universitas Riau juga sudah berlangganan jurnal online berupa database yaitu SpingerLink, Westlaw, Emerald, Cambridge University, Clinical KEY, dan Cengage Learning. Masing-masing jurnal tersebut dilanggan pada tahun 2019 yang dapat diakses di https://lib.unri.ac.id/ dengan menggunakan jaringan internet yang ada pada Universitas Riau. Adapun jumlah jurnal online yang dilanggan lebih dari 5.000 judul yang dapat ditemukan di https://lib.unri.ac.id/ terdiri dari beragam disiplin ilmu yang dibutuhkan, terutama oleh civitas academica Universitas Riau.

Peneliti menjadikan jurnal online bagian dari penelitian ini dikarenakan jurnal online banyak diakses terutama oleh civitas academica, serta banyak juga perpustakaan yang sudah berlangganan jurnal online seperti Perpustakaan Universitas Lancang Kuning, Perpustakaan Universitas Riau, dan perpustakaan lainnya. Jurnal online yang dilanggan oleh perpustakaanperpustakaan di atas ditemukan bahwa jumlah jurnal yang dilanggan oleh Perpustakaan Universitas Riau lebih banyak dibandingkan perpustakaan lainnya. Universitas Lancang Kuning melanggan sebanyak 6 database jurnal, sedangkan Universitas Riau seperti yang disebutkan di atas. Itulah mengapa peneliti tertarik untuk menjadikan Perpustakaan Universitas Riau sebagai tempat penelitian pada penelitian ini.

Berdasarkan observasi yang peneliti lakukan di Perpustakaan Universitas Riau, ditemukan 
Palimpsest: Journal of Information and Library Science Vol 12, Issue 2, (2021), page 87-98

bahwa mahasiswa yang telah menyelesaikan dan menyerahkan skripsi pada tahun 2019 sebanyak 5.621 judul skripsi. Terdapat sejumlah mahasiswa yang tidak menggunakan jurnal online langganan, namun ada juga mahasiswa yang telah menggunakan database jurnal online yang dilanggan oleh Perpustakaan Universitas Riau seperti SpingerLink, Westlaw, Emerald, Cambridge University, Clinical KEY, dan Cengage Learning. Untuk itu peneliti tertarik untuk melakukan penelitian dengan judul Efektivitas Pemakaian Jurnal Online oleh Mahasiswa di Perpustakaan Universitas Riau, dengan tujuan untuk mengetahui bagaimana efektivitas pemakaian jurnal online oleh mahasiswa di Perpustakaan Universitas Riau.

\section{Metode Penelitian}

Jenis penelitian ini ialah deskriptif dengan menggunakan pendekatan kuantitatif. Adapun teknik pengumpulan data dilakukan dengan observasi, wawancara, dan dokumentasi. Variabel pada penelitian ini adalah efektivitas pemakaian jurnal online oleh mahasiswa di Perpustakaan Universitas Riau dengan tiga indikator menurut Thomson (dalam Urrahmah Aulia, 2019:52) yaitu intensitas penggunaan (intensity of use), frekuensi penggunaan (frequency of use), dan jumlah yang digunakan (diversity of software pachage use). Penghitungan jumlah sampel menggunakan rumus Slovin dengan tingkat kesalahan 5\% (dalam Amaliah, 2017:12)

$$
n=\frac{N}{1+N \cdot e^{2}}
$$

Adapun analisis data merupakan proses mengatur urutan data, mengorganisasikannya kedalam suatu pola, kategori, dan satuan uraian dasar. Patton dalam Niana (dalam Suryadi, 2020:21)

$$
P=\frac{f}{N} x 100 \%
$$

Dalam proses menafsirkan data, penelitian ini menggunakan pedoman penafsiran data yang dilakukan Supardi dalam Niana (dalam Suryadi, 2020:22). Pada penafsiran ini besar angka yang dipakai menggunakan dua belakang koma yaitu,

$$
\begin{array}{ll}
0,00 \% & =\text { Tidak ada } \\
1,00 \%-24,99 \% & =\text { Sebagian kecil } \\
25,00 \%-49,99 \% & =\text { Hampir setengahnya } \\
50,00 \% & =\text { Setengahnya } \\
50,01 \%-74,99 \% & =\text { Pada umumnya } \\
75,00 \%-99,99 \% & =\text { Hampir seluruhnya } \\
100 \% & =\text { Seluruhnya }
\end{array}
$$

Untuk menghitung efektivitas pemakaian jurnal online dapat dirumuskan sebagai berikut (Abdul dalam Pangkey Imanuel, 2015:37)

$$
\text { Rasio Efektivitas }=\frac{\text { Realisasi Pemakaian Jurnal Online }}{\text { Target Pemakaian Jurnal Online }} \times 100 \%
$$


Palimpsest: Journal of Information and Library Science Vol 12, Issue 2, (2021), page 88-98

Sedangkan untuk efektivitas diukur menggunakan standar sesuai acuan Litbang Depdagri (dalam Wiyati, 2015:563).

\section{Hasil dan Pembahasan}

Penelitian ini ditujukan untuk menjawab rumusan masalah yaitu mengenai bagaimana efektivitas pemakaian jurnal online oleh mahasiswa di Perpustakaan Universitas Riau. Adapun jumlah penelitian dalam bentuk skripsi yang diteliti dalam penelitian ini yaitu sejumlah 373 skripsi yang dilakukan oleh mahasiswa Universitas Riau tahun 2019. Skripsi tersebut masingmasing berasal dari 10 fakultas yang ada di Universitas Riau yaitu Fakultas Kedokteran (FK), Fakultas Perikanan dan Ilmu Kelautan (FAPERIKA), Fakultas Keguruan dan Ilmu Pendidikan (FKIP), Fakultas Matematika dan Ilmu Pengetahuan Alam (FMIPA), Fakultas Sosial dan Ilmu Politik (FISIP), Fakultas Pertanian (FAPERTA), Fakultas Teknik (FT), Fakultas Keperawatan (FKp), Fakultas Ekonomi dan Bisinis (FEB), dan Fakultas Hukum (FH).

Pada penelitian ini, penulis akan meneliti enam database jurnal online yang dilanggan oleh Perpustakaan Universitas Riau. Enam database jurnal tersebut di antaranya adalah SpingerLink, Westlaw, Emerald, Cambridge University, Clinical KEY, dan Cengage Learning. Akan tetapi, setelah turun ke lapangan penulis hanya bisa meneliti tiga database jurnal online saja dikarenakan tiga jurnal online lainnya masih dalam proses perpanjangan. Adapun tiga database jurnal yang masih berlanggganan yaitu ProQuest, Emerald, dan Westlaw. Untuk lebih rinci dapat diperhatikan pada Tabel 1 berikut ini,

Tabel 1.

Jurnal online langganan Universitas Riau tahun 2019

\begin{tabular}{|c|c|c|}
\hline Database Jurnal & Bidang Ilmu & Fakultas \\
\hline ProQuest & $\begin{array}{l}\text { 1. ProQuest Medical: Disiplin Klinis dan Kesehatan } \\
\text { (Kardiovaskular, penyakit, Pediatri, Neurologi, } \\
\text { Penyakit Pernapasan, Kedokteran Gigi, Anastesi, dan } \\
\text { Lainnya). } \\
\text { 2. ProQuest Research Library: Bisinis Seni, } \\
\text { Pendidikan, Kesehatan dan Kedokteran, Sejarah, } \\
\text { Hukum, Sastra dan Bahasa, Multikultural, Psikologi, } \\
\text { Ilmu Alam, Ilmu Sosial, Teknik, dan Teknologi. }\end{array}$ & $\begin{array}{l}\text { FK, FKp, FAPERIKA, } \\
\text { FKIP, FMIPA, FISIP, } \\
\text { FT, FH, FAPERTA. }\end{array}$ \\
\hline Emerald & $\begin{array}{l}\text { Akuntansi, Keuangan dan Ekonomi, Pendidikan, Teknik, } \\
\text { Pemasaran, Kebijakan Publik dan Manajemen } \\
\text { Lingkungan. }\end{array}$ & FEB, FKIP, FT. \\
\hline Westlaw & Ilmu Hukum. & $\mathrm{FH}$ \\
\hline
\end{tabular}

Sumber: Data diolah Mei 2021

Tabel 2.

Skripsi mahasiswa Universitas Riau tahun 2019

\begin{tabular}{lllcc}
\hline No. & \multicolumn{1}{c}{ Fakultas } & \multicolumn{1}{c}{ Prodi/Jurusan } & F & Tahun \\
\hline 1. & FEB & Akuntansi & 7 & 2019 \\
& & Ilmu Ekonomi & 7 & \\
& & Manajemen & 7 & \\
2. & FH & Hukum Pidana & 7 & 2019
\end{tabular}


Palimpsest: Journal of Information and Library Science Vol 12, Issue 2, (2021), page 89-98

\begin{tabular}{|c|c|c|c|c|}
\hline No. & Fakultas & Prodi/Jurusan & $\mathbf{F}$ & Tahun \\
\hline & & Hukum Perdata & 7 & \\
\hline & & Hukum Tata Negara & 8 & \\
\hline & & Hukum Internasional & 7 & \\
\hline 3. & FK & Kedokteran & 7 & 2019 \\
\hline 4. & FKp & Keperawatan & 7 & 2019 \\
\hline \multirow[t]{6}{*}{5.} & FAPERIKA & Pemanfaatan Sumberdaya Perikanan & 7 & 2019 \\
\hline & & Budidaya Perairan & 7 & \\
\hline & & Manajemen Sumberdaya Perairan & 7 & \\
\hline & & Teknologi Hasil Perikanan & 8 & \\
\hline & & Ilmu Kelautan & 7 & \\
\hline & & Sosial Ekonomi Perikanan & 7 & \\
\hline \multirow[t]{5}{*}{6.} & FISIP & Hubungan Internasional & 7 & 2019 \\
\hline & & Ilmu Komunikasi & 7 & \\
\hline & & Ilmu Pemerintahan & 8 & \\
\hline & & Ilmu Sosiologi & 7 & \\
\hline & & Ilmu Administrasi & 7 & \\
\hline \multirow[t]{16}{*}{7.} & FKIP & Pendidikan Matematika & 7 & 2019 \\
\hline & & Pendidikan Biologi & 7 & \\
\hline & & Pendidikan Fisika & 8 & \\
\hline & & Pendidikan Kimia & 7 & \\
\hline & & Pendidikan Masyarakat & 7 & \\
\hline & & Pendidikan Anak Usia Dini & 7 & \\
\hline & & Pendidikan Guru Sekolah Dasar & 7 & \\
\hline & & Pendidikan Bahasa \& Sastra Inggris & 7 & \\
\hline & & Pendidikan Bahasa \& Sastra Jepang & 8 & \\
\hline & & Pendidikan Bahasa \& Sastra Indonesia & 7 & \\
\hline & & Pendidikan Ekonomi & 7 & \\
\hline & & Pendidikan Sejarah & 7 & \\
\hline & & Pendidikan Pancasila \& Kewarganegaraan & 7 & \\
\hline & & Pendidikan Jasmani Kesehatan \& Rekreasi & 7 & \\
\hline & & Pendidikan Kepelatihan Olahraga & 7 & \\
\hline & & Bimbingan Konseling & 8 & \\
\hline \multirow[t]{5}{*}{8.} & FMIPA & Sistem Informasi/Ilmu Komputer & 7 & 2019 \\
\hline & & Matematika & 8 & \\
\hline & & Kimia & 7 & \\
\hline & & Fisika & 7 & \\
\hline & & Biologi & 7 & \\
\hline \multirow[t]{7}{*}{9.} & FT & Teknik Sipil & 8 & 2019 \\
\hline & & Teknik Kimia & 7 & \\
\hline & & Teknik Elektro & 7 & \\
\hline & & Arsitektur & 7 & \\
\hline & & Teknik Mesin & 7 & \\
\hline & & Teknik Lingkungan & 7 & \\
\hline & & Teknik Informatika & 7 & \\
\hline \multirow[t]{2}{*}{10.} & FAPERTA & Teknologi Pertanian & 8 & 2019 \\
\hline & & Kehutanan & 7 & \\
\hline
\end{tabular}


Palimpsest: Journal of Information and Library Science Vol 12, Issue 2, (2021), page 90-98

\begin{tabular}{|c|c|c|}
\hline Fakultas & Prodi/Jurusan & Tahun \\
\hline & Agribisnis & 7 \\
\hline & Agroteknologi & 7 \\
\hline Total Keseluruhan & 52 Prodi & 373 Skripsi \\
\hline
\end{tabular}

Sumber: Data diolah Mei 2021

Dari Tabel 2 dapat diketahui bahwa total keseluruhan jumlah skripsi mahasiswa yang peneliti teliti adalah pada sebanyak 373 skripsi. Dari 373 skripsi tersebut peneliti membagi dengan 10 Fakultas dengan strata 1 (S1) yang ada di Universitas Riau dengan jumlah program studi sebanyak 52. Maka didapatkan data dari FEB 21 skripsi, FH 29 skripsi, FK 7 skripsi, FKp 7 skripsi, FAPERIKA 43 skripsi, FISIP 36 skripsi, FKIP 115 skripsi, FMIPA 36 skripsi, FT 50 skripsi, dan FAPERTA 29 skripsi.

\section{Keterpakaian Jurnal}

Dalam penelitian ini, peneliti menelusuri tiga keterpakaian jurnal online langganan Universitas Riau, yang pertama yaitu Westlaw. Dari data yang didapat menunjukkan bahwa penelitian yang dilakukan oleh mahasiswa Universitas Riau pada tahun 2019 sebanyak 373 jumlah penelitian, terdapat 22 penelitian dengan penelitian yang berbeda dengan 59 referensi.

Tabel 3.

Jumlah keseluruhan keterpakaian jurnal online Westlaw oleh mahasiswa Universitas Riau tahun 2019

\begin{tabular}{ccccc}
\hline Jumlah Penelitian & Terpakai & \% & Tidak Terpakai & \% \\
\hline 373 & 22 & 5,89 & 351 & 94,10 \\
\hline
\end{tabular}

Sumber: Data diolah Mei 2021

Dari Jurnal Emerald, 373 jumlah penelitian, peneliti tidak menemukan ada penelitian yang menggunakan kutipan atau referensi dari database Jurnal Emerald. Hal ini dikarenakan dari 373 jumlah penelitian yang peneliti temukan di lapangan, kebanyakan mahasiswa mengutip dari Jurnal Online Mahasiswa (JOM) yang telah disediakan oleh pihak Universitas Riau di masingmasing fakultas. Selanjutnya keterpakaian Jurnal ProQuest menunjukkan bahwa 373 jumlah penelitian terdapat 24 judul penelitian yang mengutip dari database Jurnal ProQuest dengan jumlah 38 referensi.

Tabel 4.

Jumlah keseluruhan keterpakaian jurnal online ProQuest oleh mahasiswa Universitas Riau tahun 2019

\begin{tabular}{ccccc}
\hline Jumlah Penelitian & Terpakai & \% & Tidak Terpakai & \% \\
\hline 373 & 24 & 6,43 & 349 & 93,56 \\
\hline
\end{tabular}

Sumber: Data diolah Mei 2021 
Palimpsest: Journal of Information and Library Science Vol 12, Issue 2, (2021), page 91-98

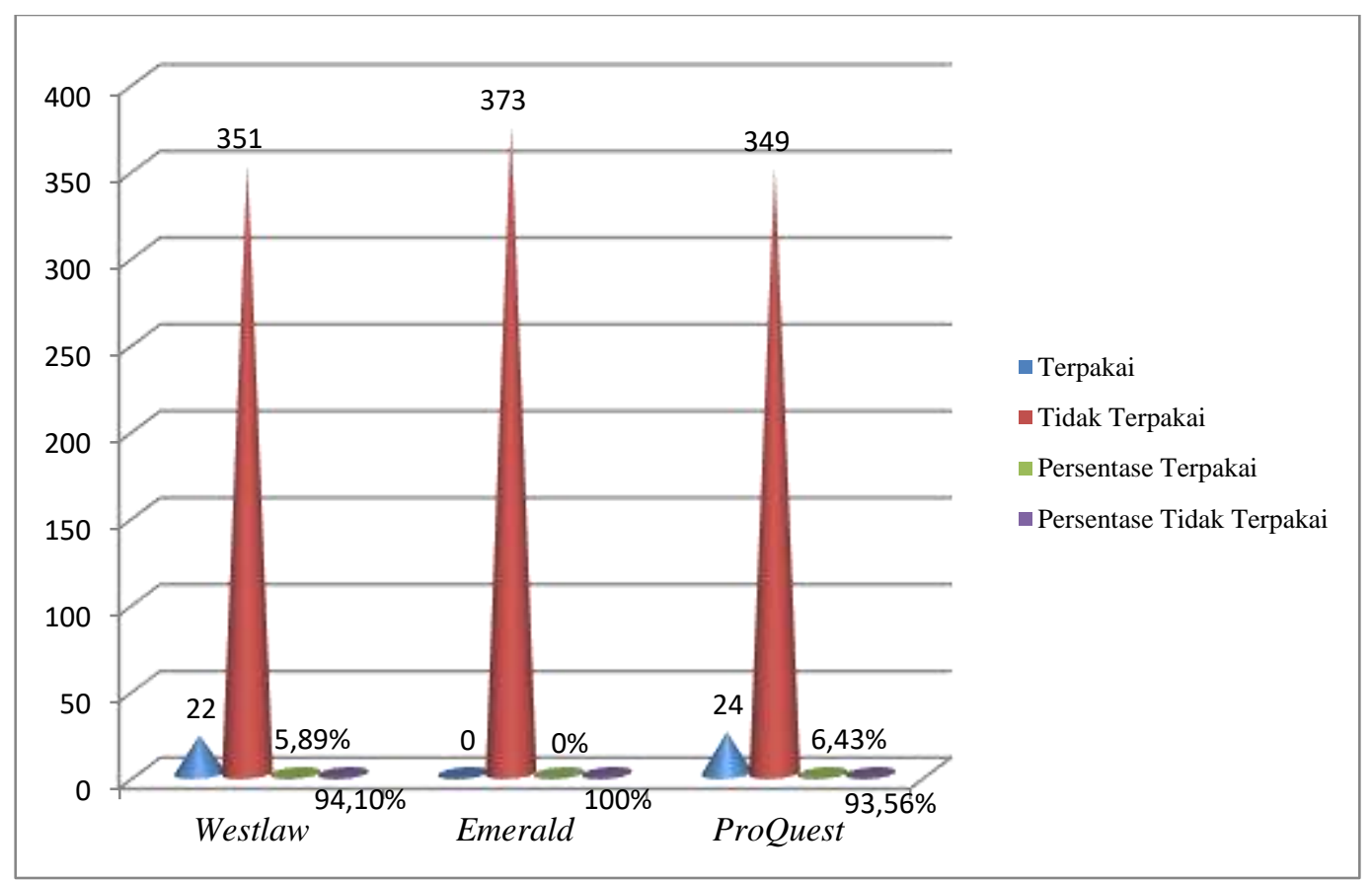

Grafik 1.

Keterpakaian jurnal online langganan Universitas Riau tahun 2019

\section{Intensitas Pengguna}

Pada penelitian ini, peneliti mencari intensitas pengguna dengan melihat keterpakaian jurnal online langganan Perpustakaan Universitas Riau di daftar pustaka skripsi mahasiswa tahun 2019. Berikut adalah tabel rincian intensitas penggunaan database jurnal,

Tabel 5.

Intensitas pengguna tahun 2019

\begin{tabular}{clccc}
\hline No. & \multicolumn{1}{c}{ Mahasiswa } & Westlaw & Emerald & ProQuest \\
\hline 1. & Iing Maidasari & 4 & - & - \\
2. & Yogi Alda Hijra & 3 & - & - \\
3. & Syafariah Rizqa & 1 & - & - \\
4. & Syafira Yasmin Nasution & 6 & - & - \\
5. & Santri Alifya & 3 & - & - \\
6. & Retno Tri Utami & 3 & - & - \\
7. & Annisa Desria Utami & 1 & - & - \\
8. & Adig Cahya & 2 & - & - \\
9. & Citra Rahmawati Lubis & 3 & - & - \\
10. & Ivan Ryian Ewaldo & 5 & - & 1 \\
11. & Hendra Pranata & 3 & - & - \\
12. & Habibur Rahman & 1 & - & - \\
13. & Kowland Hawary & 5 & - & - \\
14. & Khorida Silvia & 3 & - & - \\
15. & Johana Supra Silaban & 2 & - & - \\
16. & Reni Lestari & 2 & - & - \\
17. & Rahmatul Fitri & 2 & - & -
\end{tabular}


Palimpsest: Journal of Information and Library Science Vol 12, Issue 2, (2021), page 92-98

\begin{tabular}{|c|c|c|c|c|}
\hline No. & Mahasiswa & Westlaw & Emerald & ProQuest \\
\hline 18. & Andi Wahyu Putra Utama & 1 & - & - \\
\hline 19. & Yolanda Melisa & 2 & - & - \\
\hline 20. & Rahmah Nur Hasanah & 5 & - & 1 \\
\hline 21. & Siti Nurrahmah & 1 & - & - \\
\hline 22. & Samuel Hamonangan Simanjuntak & 1 & - & - \\
\hline 23. & Wahyu Asdi Pradana & - & - & 2 \\
\hline 24. & Dhea Ayu Kartini Surya Putri & - & - & 1 \\
\hline 25. & Wendiono Alka & - & - & 1 \\
\hline 26. & Qurnia Siti Hurulaini & - & - & 3 \\
\hline 27. & Vadyan Haz Kamal & - & - & 2 \\
\hline 28. & May Ave Maria Tobing & - & - & 1 \\
\hline 29. & Emmelia Christin $\mathrm{S}$ & - & - & 1 \\
\hline 30. & Mhd. Azaldin & - & - & 1 \\
\hline 31. & Anjeli Y Hutasoit & - & - & 1 \\
\hline 32. & Habibullah Alhaqiqi & - & - & 1 \\
\hline 33. & Junida Lamrotua Siregar & - & - & 2 \\
\hline 34. & Rise Desva Sari & - & - & 1 \\
\hline 35 & Rizka Desria Asri & - & - & 4 \\
\hline 36. & Feny Hartati & - & - & 1 \\
\hline 37. & Jr. Lessy Eka Putri & - & - & 1 \\
\hline 38. & Mailestari Wina Yance & - & - & 1 \\
\hline 39. & Putri Novika Lestari & - & - & 1 \\
\hline 40. & Bella Permata Cindy & - & - & 1 \\
\hline 41. & Mahatir M Tamher & - & - & 7 \\
\hline 42. & Annisa Nur'alifa & - & - & 1 \\
\hline 43. & Irvan Rahman & - & - & 1 \\
\hline 44. & Kharomatul Umma & - & - & 1 \\
\hline \multicolumn{2}{|r|}{ Total Keseluruhan } & 22 & $\mathbf{0}$ & 24 \\
\hline
\end{tabular}

Sumber: Data diolah Mei 2021

\section{Frekuensi Penggunaan}

Frekuensi pengguna yaitu dilihat dari hasil keterpakaian masing-masing jurnal online langganan Universitas Riau yaitu pengguna yang sering menggunakan referensi tersebut dalam menyelesaikan skripsinya pada tahun 2019. Berikut adalah tabel rincian frekuensi tertinggi dalam penggunaan database jurnal,

Tabel 6.

Frekuensi pengguna tahun 2019

\begin{tabular}{llccc}
\hline No. & Mahasiswa & Westlaw & Emerald & ProQuest \\
\hline 1. & Syafirah Yasmin Nasution & 6 & - & - \\
2. & Mahatir M Tamher & - & - & 7 \\
\hline
\end{tabular}

Sumber: Data diolah Mei 2021 
Palimpsest: Journal of Information and Library Science Vol 12, Issue 2, (2021), page 93-98

\section{Jumlah Referensi yang Digunakan}

Berdasarkan penelitian ini, peneliti dapat melihat jumlah keseluruhan dari hasil penelitian yang digunakan untuk mencari referensi dalam menyelesaikan skripsi tahun 2019. Berikut adalah tabel jumlah referensi yang diambil dari database jurnal dan digunakan dalam skripsi,

Tabel 7.

Jumlah yang menggunakan jurnal Westlaw tahun 2019

\begin{tabular}{|c|c|c|c|}
\hline No & Mahasiswa & Judul & $\begin{array}{c}\text { Jumlah } \\
\text { Referensi }\end{array}$ \\
\hline 1. & Iing Maida Sari & $\begin{array}{l}\text { Tindakan Personan Non Grata Terhadap Pejabat } \\
\text { Diplomatik (Studi Persona Non Grata Pejabat } \\
\text { Diplomatik Rusia Untuk PBB oleh Negara } \\
\text { Amerika Serikat }\end{array}$ & 4 \\
\hline 2. & Reni Lestari & $\begin{array}{l}\text { Politik Hukum Pembentukan Kantor Staf } \\
\text { Presiden Nomor } 26 \text { Tahun } 2015 \text { Tentang } \\
\text { Kantor Staf Presiden }\end{array}$ & 2 \\
\hline 3. & Rahmatul Fitri & $\begin{array}{l}\text { Tinjauan Hukum Administrasi Negara Dalam } \\
\text { Bidang Pengelolaan Sampah Sebagai } \\
\text { Perwujudan Prinsip Good Environmental } \\
\text { Governance di Kota Pekanbaru }\end{array}$ & 2 \\
\hline 4. & Syafariah Rizqa & $\begin{array}{l}\text { Analisis Yuridis Tindakan Sepihak Penarikan } \\
\text { Perwakilan Diplomatik Suatu Negara Dalam } \\
\text { Kaidah Hukum Internasional (Studi } \\
\text { Perbandingan Antara Kasus Duta Besar } \\
\text { Norwegia Untuk Indonesia dan Duta Besar } \\
\text { Jepang Untuk Korea Selatan) }\end{array}$ & 1 \\
\hline 5. & Adig Cahya & $\begin{array}{l}\text { Akibat Hukum Pembatalan Perkawinan } \\
\text { Poligami Terhadap Istri Ke-2 (Dua) Ditinjau } \\
\text { Dari Undang-Undang Nomor } 1 \text { Tahun } 1974 \\
\text { Tentang Perkawinan Dan Kompilasi Hukum } \\
\text { Islam }\end{array}$ & 2 \\
\hline 6. & $\begin{array}{l}\text { Citra Rahmawati } \\
\text { Lubis }\end{array}$ & $\begin{array}{l}\text { Analisis Hukum Pelaksanaan Perjanjian } \\
\text { Kerjasama Pelayanan Administrasi Operasional } \\
\text { Jasa Pemanduan Kapal Antara PD. Pelabuhan } \\
\text { Dumai Bersemai (BUMD) Dengan PT. } \\
\text { Pelabuhan Tiga Bersaudara Yang Berakibat } \\
\text { Wanprestasi }\end{array}$ & 3 \\
\hline 7. & Irvan Riyan Ewaldo & $\begin{array}{l}\text { Tinjauan Perkawinan Kedua (Poliandri) Tanpa } \\
\text { Perceraian Dalam Adat Toba Di Desa Lubuk } \\
\text { Ogung Kecamatan Sei Kijang Kabupaten } \\
\text { Pelalawan }\end{array}$ & 5 \\
\hline 8. & Hendra Pranata & $\begin{array}{l}\text { Pengelolaan Tanah Adat Pada Masyarakat Adat } \\
\text { Batak Toba Di Kelurahan Barisan Pancur Nauli } \\
\text { Kota Pematang Siantar }\end{array}$ & 3 \\
\hline
\end{tabular}


Palimpsest: Journal of Information and Library Science Vol 12, Issue 2, (2021), page 94-98

\begin{tabular}{|c|c|c|c|}
\hline No & Mahasiswa & Judul & $\begin{array}{c}\text { Jumlah } \\
\text { Referensi }\end{array}$ \\
\hline 9. & Habibur Rahman & $\begin{array}{l}\text { Kajian Tentang Hak Kesehatan Pekerja } \\
\text { Perkebunan Sawit Pada Koperasi Pesantren } \\
\text { Darussalam Desa Saran Kabun Kabupaten } \\
\text { Rokan Hulu }\end{array}$ & 1 \\
\hline 10. & Retno Tri Utami & $\begin{array}{l}\text { Implikasi Yuridis Perjanjian Perbatasan } \\
\text { Maritim Australia-Timor Leste Tahun } 2018 \\
\text { Terhadap Perjanjian Batas Wilayah Laut } \\
\text { Indonesia-Australia Tahun } 1972\end{array}$ & 3 \\
\hline 11. & Yogi Alda Hijra & $\begin{array}{l}\text { Akibat Hukum Kebijakan Zero Tolerance } \\
\text { Amerika Serikat Terhadap Anak Dari Migran } \\
\text { Dalam Perspektif Hak Asasi Manusia } \\
\text { Internasional }\end{array}$ & 3 \\
\hline 12. & $\begin{array}{l}\text { Syafira Yasmin } \\
\text { Nasution }\end{array}$ & $\begin{array}{l}\text { Implikasi Paris Agreement } 2015 \text { Terhadap } \\
\text { Kebijakan Pemerintah Indonesia Di Sektor } \\
\text { Energi Dalam Mitigasi Perubahan Iklim Di } \\
\text { Indonesia (Kebijakan Penggunaan Energi } \\
\text { Batubara Dalam Pembangunan di Indonesia) }\end{array}$ & 6 \\
\hline 13. & Santri Alifya & $\begin{array}{l}\text { Tinjauan Yuridis Penyelesaian Perkasa } \\
\text { Kepailitan Antara PT. Mimi Kids Garmindo } \\
\text { Dengan Bank Nusantara Parahyangan di Jawa } \\
\text { Barat }\end{array}$ & 3 \\
\hline 14. & Kowland Hawary & $\begin{array}{l}\text { Gagasan Pemidanaan Terhadap Pelaku } \\
\text { Persetubuhan Dengan Mayat (Necrophilia) } \\
\text { Dalam Hukum Positif Indonesia }\end{array}$ & 5 \\
\hline 15. & Khorida Silvia & $\begin{array}{l}\text { Perbandingan Konsep Tindak Pidanamarital } \\
\text { Rape di Dalam Rumah Tangga Berdasarkan } \\
\text { Undang-Undang Nomor } 23 \text { Tahun } 2004 \\
\text { Tentang Penghapusan Kekerasan Dalam Rumah } \\
\text { Tangga Dan Hukum Islam }\end{array}$ & 3 \\
\hline 16. & Johana Supra Silaban & $\begin{array}{l}\text { Pertanggungjawaban Pidana Tenaga Medis } \\
\text { Yang Melakukan Kesalahan Diagnosa } \\
\text { Terhadap Pasien Berdasarkan Undang-Undang } \\
\text { Nomor } 36 \text { Tahun } 2014 \text { Tentang Tenaga } \\
\text { Kesehatan }\end{array}$ & 2 \\
\hline 17. & Yolanda Melisa & $\begin{array}{l}\text { Pelaksanaan Pendidikan Politik Bagi } \\
\text { Masyarakat Oleh Partai Politik Kota Pekanbaru } \\
\text { Berdasarkan Undang-Undang Nomor } 2 \text { Tahun } \\
2011 \text { Tentang Partai Politik }\end{array}$ & 2 \\
\hline 18. & Rahmah Nur Hasanah & $\begin{array}{l}\text { Gagasan Penataan Mekanisme Impeachment } \\
\text { Presiden Dan/Atau Wakil Presiden Dalam } \\
\text { Ketatanegaraan Indonesia }\end{array}$ & 5 \\
\hline 19. & $\begin{array}{l}\text { Samuel Hamonangan } \\
\text { Simanjuntak }\end{array}$ & $\begin{array}{l}\text { Tinjauan Yuridis Terhadap Kewenangan } \\
\text { Komisi Kejaksaan Republik Indonesia } \\
\text { Berdasarkan Peraturan Presiden Nomor } 18 \\
\text { Tahun } 2021 \text { Tentang Komisi Kejaksaan } \\
\text { Republik Indonesia }\end{array}$ & 1 \\
\hline
\end{tabular}


Palimpsest: Journal of Information and Library Science Vol 12, Issue 2, (2021), page 95-98

\begin{tabular}{lll} 
20. Siti Nurrahmah & Gagasan Mencegah Timbulnya Calon Tunggal & \\
& Pada Pemilihan Kepala Daerah Serentak Dalam & 1 \\
& Perspektif Demokrasi di Indonesia \\
& Tinjauan Yuridis Pengisian Jabatan Wakil \\
& Bupati Berdasarkan Undang-Undang Nomor 10 \\
& Tahun 2016 Tentang Perubahan Kedua & \\
& Undang-Undang Nomor 1 Tahun 2015 Tentang & 1 \\
21. Andi Putra Utama & Penetapan Peraturan Pemerintah Pengganti & \\
& Undang-Undang Nomor 1 Tahun 2014 Tentang & \\
& Pemilihan Gubernur, Bupati Dan Walikota & \\
& Pelaksanaan Perkawinan Sesuku Masyarakat & \\
& Suku Melayu Berdasarkan Hukum Adat di & \\
22. Annisa Desria Utami & Nagari Padang Sibusuk Kecamatan Kupitan & \\
& Kabupaten Sijunjung \\
\hline Total Keseluruhan & & $\mathbf{5 9}$ \\
\hline
\end{tabular}

Sumber: Data diolah Mei 2021

Dari data pada Tabel 7 dapat diketahui jumlah mahasiswa yang menggunakan Jurnal Westlaw sebagai bahan referensi yaitu sebanyak 22 penelitian dengan 59 referensi dari total 373 penelitian yang peneliti temukan di lapangan. Jika dilihat dari standar ukuran efektivitas sesuai acuan Litbang Depdagri yang telah dijelaskan di atas, maka tingkat keterpakaian Jurnal online Westlaw sangat tidak efektif yaitu senilai 5,89\%, karena rasio efektivitasnya di bawah 40 .

Sedangkan jumlah yang menggunakan Jurnal Emerald ditemukan bahwasanya tidak ada satupun penelitian yang menggunakan database Jurnal Emerald pada tahun 2019. Maka dapat dinyatakan bahwasanya keterpakaian jurnal online langganan Emerald sangat-sangat tidak efektif untuk dilanggan, karena pihak Perpustakaan Universitas Riau melanggan Jurnal Emerald sebanyak 300 jurnal dengan ribuan artikel di dalamnya.

Selanjutnya yaitu jumlah yang menggunakan Jurnal ProQuest sebagai acuan dalam menyelesaikan skripsinya.

Tabel 8.

Jumlah yang menggunakan jurnal ProQuest tahun 2019

\begin{tabular}{cllc}
\hline No & Mahasiswa & \multicolumn{1}{c}{ Judul } & $\begin{array}{c}\text { Jumlah } \\
\text { Referensi }\end{array}$ \\
\hline 1. & Wahyu Asdi & $\begin{array}{l}\text { Evaluasi Penggunan Antibiotik Empirik Pada Pasien } \\
\text { Sepsis Intensive Care Unit (ICU) RSUD Arifin } \\
\text { Achmad Provinsi Riau Periode Januari-Desember 2017 }\end{array}$ & 2 \\
& Dhea Ayu & Efek Asam Alfa Lipoat Terhadap Kolagen Matriks & \\
2. & Kartini Surya & Ekstraseluler Sel $\beta$ Pankreas Pada Tikus Diabetes & 1 \\
& Putri & Melitus Tipe 2 & \\
& & Evaluasi Metode Pengaduk Magnetik Sebagai Metode & \\
3. & Putri Novika & Alternatif Pengganti Jar Test Pada Koagulasi & \\
& Lestari & Pengolahan Air: Pengaruh Kecepatan dan Waktu & \\
& & Pengadukan Cepat & \\
4. & Anjeli Y & Uji Metabolit Sekunder Bakteri Heterotrofik Dari Air & \\
& Hutasoit & Laut Desa Sungai Kayu Ara Kabupaten Siak Terhadap & \\
5. & Wendiono & Gakteri Patogen & \\
& & & 1
\end{tabular}


Palimpsest: Journal of Information and Library Science Vol 12, Issue 2, (2021), page 96-98

\begin{tabular}{|c|c|c|c|}
\hline No & Mahasiswa & Judul & $\begin{array}{c}\text { Jumlah } \\
\text { Referensi }\end{array}$ \\
\hline & Alka & $\begin{array}{l}\text { Formaldehid Dan Campuran Formaldehid Dengan } \\
\text { Gliserin Terhadap Organ Jantung Tikus Putih (Rattus } \\
\text { norvegicus) Galur Wistar }\end{array}$ & \\
\hline 6. & $\begin{array}{l}\text { Qurnia Siti } \\
\text { Hurulaini }\end{array}$ & $\begin{array}{l}\text { Gambaran Jumlah Neutrofil Darah Tepi Pasien } \\
\text { Penyakit Paru Obstruktiif Kronik (PPOK) Di Ruang } \\
\text { Rawat Inap RSUD Arifin Achmad Provinsi Riau Tahun } \\
2017\end{array}$ & 3 \\
\hline 7. & $\begin{array}{l}\text { Vadyan Haz } \\
\text { Kamal }\end{array}$ & $\begin{array}{l}\text { Faktor-Faktor Yang Berhubungan Dengan Keluhan } \\
\text { Kelelahan Mata Pada Pengemudi Bus Di Terminal } \\
\text { Bandar Raya Payung Sekaki Pekanbaru }\end{array}$ & 2 \\
\hline 8. & $\begin{array}{l}\text { May Ave } \\
\text { Maria Tobing }\end{array}$ & $\begin{array}{l}\text { Gambaran Peran Orangtua Dalam Memberikan } \\
\text { Pendidikan Seks Pada Remaja Difabel Di SLB }\end{array}$ & 1 \\
\hline 9. & $\begin{array}{l}\text { Emmelia } \\
\text { Christin S }\end{array}$ & $\begin{array}{l}\text { Hubungan Kecanduan Games Online Terhadap } \\
\text { Perkembangan Psikososial Anak Usia Sekolah }\end{array}$ & 1 \\
\hline 10. & $\begin{array}{l}\text { Jr. Lessy Eka } \\
\text { Putri }\end{array}$ & $\begin{array}{l}\text { Analisa Penggunaan Hyperspectral Imaging Pada Daun } \\
\text { Untuk Pendeteksian Kekurangan Air Pada Tanaman } \\
\text { Kelapa Sawit }\end{array}$ & 1 \\
\hline 11. & $\begin{array}{l}\text { Mailestari } \\
\text { Wina Yance }\end{array}$ & $\begin{array}{l}\text { Analisa Penggunaan Metode Hyperspectral Imaging } \\
\text { Pada Akar Untuk Deteksi Tingkat Kekurangan Air Pada } \\
\text { Tanaman Kelapa Sawit }\end{array}$ & 1 \\
\hline 12. & $\begin{array}{l}\text { Bella Permata } \\
\text { Cindy }\end{array}$ & $\begin{array}{l}\text { Aktivitas Katalitik Mangan Oksida Yang Didoping } \\
\text { Dengan Logam Transisi Menggunakan } 2 \text { Metode } \\
\text { Berbeda }\end{array}$ & 1 \\
\hline 13. & $\begin{array}{l}\text { Mahatir M } \\
\text { Tamher }\end{array}$ & $\begin{array}{l}\text { Perbandingan Aktivitas Lakase } \\
\text { Trichoderma Asperellum Lbkurcc1 Dalam Oksidasi } \\
\text { Substrat Abts, Guaiacol dan Syringaldazine }\end{array}$ & 7 \\
\hline 14. & $\begin{array}{l}\text { Annisa } \\
\text { Nur'alifa }\end{array}$ & $\begin{array}{l}\text { Pemetaan Tempat Penampungan Sementara (TPS) } \\
\text { Ilegal Menggunakan Sistem Informasi Geografis (SIG) } \\
\text { di Kota Tembilahan }\end{array}$ & 1 \\
\hline 15. & $\begin{array}{l}\text { Ivan Ryian } \\
\text { Ewaldo }\end{array}$ & $\begin{array}{l}\text { Tinjauan Perkawinan Kedua (Poliandri) Tanpa } \\
\text { Perceraian Dalam Adat Toba Di Desa Lubuk Ogung } \\
\text { Kecamatan Sei Kijang Kabupaten Pelalawan }\end{array}$ & 1 \\
\hline 16. & $\begin{array}{l}\text { Rahmah Nur } \\
\text { Hasanah }\end{array}$ & $\begin{array}{l}\text { Gagasan Penataan Mekeanisme Impeachment Presiden } \\
\text { Dan/Atau Wakil Presiden Dalam Ketatanegaraan } \\
\text { Indonesia }\end{array}$ & 1 \\
\hline 17. & $\begin{array}{l}\text { Kharomatul } \\
\text { Umma }\end{array}$ & $\begin{array}{l}\text { Diploma Indonesia Terhadap Negara Kontributor } \\
\text { Dalam Misi UNIFIL (United Nations Interim Force In } \\
\text { Lebanon) Tahun 2016-2018 }\end{array}$ & 1 \\
\hline 18. & $\begin{array}{l}\text { Habibullah } \\
\text { Alhaqiqi }\end{array}$ & $\begin{array}{l}\text { Kerjasama Ekonomi Amerika Serikat Dan India Pasca } \\
\text { Quantitative Easing Tahun 2008-2012 }\end{array}$ & 1 \\
\hline 19. & $\begin{array}{l}\text { Junida } \\
\text { Lamrotua } \\
\text { Siregar }\end{array}$ & $\begin{array}{l}\text { Peran United Nations Environment Programme } \\
\text { (UNEP) Dalam Menangani Solusi Marine Plastic } \\
\text { Debris Di Laut Asia Timur }\end{array}$ & 2 \\
\hline
\end{tabular}




\begin{tabular}{|c|c|c|c|}
\hline No & Mahasiswa & Judul & $\begin{array}{c}\text { Jumlah } \\
\text { Referensi }\end{array}$ \\
\hline 20. & $\begin{array}{l}\text { Rise Desva } \\
\text { Sari }\end{array}$ & $\begin{array}{l}\text { The Correlation Between Students Grammatical } \\
\text { Knowledge And The Ability In Translating Indonesian } \\
\text { English Narrative Texts By The Second Years Students } \\
\text { Of SMAN } 1 \text { Sentajo Raya }\end{array}$ & 1 \\
\hline 21. & $\begin{array}{l}\text { Rizka Desria } \\
\text { Asri }\end{array}$ & $\begin{array}{l}\text { The Corelation Between Self-Esteem And Writing } \\
\text { Ability Of The First Year Students Of SMAN } 1 \\
\text { Pekanbaru }\end{array}$ & 4 \\
\hline 22. & Feny Hartati & $\begin{array}{l}\text { A Study On The Ability Of The Eighth Year Students Of } \\
\text { SMP Negeri } 4 \text { Pekanbaru In Comprehending Recount } \\
\text { Texts }\end{array}$ & 1 \\
\hline 23. & Mhd. Azaldin & $\begin{array}{l}\text { Sensitivitas Ekstrak Kulit Nanas (Ananas comosus) } \\
\text { Terhadap Bakteri Edwarsiella tarda }\end{array}$ & 1 \\
\hline 24. & Irvan Rahman & $\begin{array}{l}\text { Pengaruh Penggunaan Suhu Berbeda Terhadap Mutu } \\
\text { Kolagen Daging Teripang Pasir (Holothuria scabra) }\end{array}$ & 1 \\
\hline \multicolumn{3}{|c|}{ Total Keseluruhan } & 38 \\
\hline
\end{tabular}

Dari data pada Tabel 8 dapat diketahui bahwa, terdapat 24 penelitian dengan nama berbeda dengan menggunakan jumlah total referensi sebanyak 38 dari database Jurnal ProQuest dari 373 jumlah penelitian skripsi pada tahun 2019. Maka dapat kita lihat keterpakaian Jurnal ProQuest sangat tidak efektif jika diukur menggunakan standar ukuran efektivitas sesuai acuan Litbang Depdagri. Adapun hasil keterpakaian Jurnal Online ProQuest pada penelitian ini yaitu senilai 6,43\%. Dengan jumlah artikel yang dilanggan pada database Jurnal ProQuest memiliki 150 subject di dalam 1 subject mengandung ribuan artikel.

\section{Kesimpulan}

Dapat disimpulkan bahwasanya tingkat keterpakaian jurnal online yang dilanggan oleh Perpustakaan Universitas Riau seperti Westlaw, Emerald, dan ProQuest tidak sesuai dengan jumlah artikel yang terdapat pada jurnal tersebut untuk memudahkan mahasiswanya dalam pengerjaan skripsi. Adapun persentase dari database Jurnal Westlaw yaitu berjumlah 5,89\% terpakai dan $94,10 \%$ tidak terpakai dengan jumlah artikel yang dilanggan sebanyak \pm 10.000 artikel. Untuk database Jurnal Emerald dengan persentase 100\% tidak terpakai dengan jumlah jurnal sebanyak 300 dengan ribuan artikel yang dilanggan. Selanjutnya database Jurnal ProQuest tingkat keterpakaiannya lebih banyak dibanding tingkat keterpakaian Westlaw dan Emerald, dengan persentase terpakai sebanyak 6,43\% dan persentase tidak terpakai sebanyak 93,56\%, dengan 150 subjek di dalam 1 subjek mengandung ribuan artikel. Dengan demikian dapat dikatakan bahwa efektivitas pemakaian jurnal online oleh mahasiswa di Perpustakaan Universitas Riau sangat tidak efektif.

\section{Daftar Pustaka}

Amaliah, M. A. Dan R. (2017). Pemanfaatan Jurnal Elektronik Sebagai Sumber Referensi Dalam Penulisan Skripsi di Institut Pertanian Bogor. Libraria, Vol. 5, 12.

Florencia, O. G. B. (2015). Efektivitas Program Corporate Social Responsibility (CSR) Bidang 
Palimpsest: Journal of Information and Library Science Vol 12, Issue 2, (2021), page 98-98

Lingkungan Hidup Pada Hotel Bintang Lima Dikawasan Pariwisata Ubud Kabupaten Gianyar. Universitas Udayana.

Hasan, T. (2013). Kajian Pemanfaatan Jurnal Online Pada Perpustakaan Universitas Riau Pekanbaru. Jurnal Gema Pustakawan, Vol. 1, 26.

Jamluddin. (2015). Mengenal Elektronik Jurnal dan Manfaatnya Bagi Pengembangan Karier Pustakawan. Jupiter, Vol. 14, 40.

Kamelta, E. (2013). Pemanfaatan Internet Oleh Mahasiswa Jurusan Teknik Sipil Fakultas Teknik $\begin{array}{llllll}\text { Universitas Negeri } & \text { Padang. } & \text { Cived, } & \text { Vol. } & 143 .\end{array}$ Https://Doi.Org/Https://Doi.Org/10.24036/Cived.V1i2.1851

Latiar, H. (2018). Pengaruh Ketersediaan dan Pemanfaatan Jurnal Online ProQuest Terhadap Pemenuhan Kebutuhan Informasi Pemustaka di UPT Universitas Negeri Yogyakarta. Universitas Negeri Yogyakarta.

Pangkey Imanuel, P. S. (2015). Analisis Efektivitas dan Efisiensi Anggaran Belanja Pada Dinas Kebudayaan dan Parawisata Provinsi Sulawesi Utara. Jurnal EMBA, Vol. 3, 37.

Rusydi, I. (2014). Pemanfaatan E-Journal Sebagai Media Informasi Digital. Jurnal Iqra', Vol. 8, 201.

Sevilla, V. (2016). Keputusan Memilih E-Journal Sebagai Sumber Informasi Ilmiah Oleh Sivitas Akademika. Prosiding Seminar Nasional Komunikasi, 207.

Sholihah, K. (2016). Analisis Literasi Digital: Studi Pemanfaatan Jurnal Elektronik Oleh Mahasiswa Magister Manajemen di Perpustakaan UKSW Salatiga. UIN Sunan Kalijaga.

Sugiyono. (2014). Metode Penelitian Kombinasi (Mixed Methods ) (Sutopo (Ed.); Cet. 6). Alfabeta.

Suryadi. (2020). Tren Topik Penulisan Karya Ilmiah Pada Jurnal Jurnal Manuskripta dan Jumantara Tahun 2015-2019. Lancang Kuning.

Urrahmah Aulia, N. M. (2019). Evaluasi Tingkat Keterpakaian Koleksi Perpustakaan di Dinas Perpustakaan dan Kearsipan Kota Padang Panjang. Jurnal Ilmu Informasi Perpustakaan dan Kearsipan, Vol. 8, 51.

Verina, O. (2020). Evaluasi Keterpakaian Jurnal Berlangganan Spingerlink dan Kesesuaian Subjek Penelitian Peneliti dan Penyuluh di Perpustakaan (BPTP) Riau. Lancang Kuning.

Wiyati, N. L. A. K. Y. S. dan R. K. (2015). Pengukuran Tingkat Efektivitas dan Efisiensi Sistem E-Research STIKOM Bali. Konferensi Nasional Sistem \& Informatika 2015, 563. 